\title{
Bedtime-related jerks in the upper limbs associated with restless arms syndrome
} 昌

Supplemental data at Neurology.org
A 73-year-old man complained at bedtime of "electric shock" sensations, corresponding to myoclonic-like jerks, observed solely in both arms, causing severe insomnia. These involuntary movements appeared at rest and were accompanied by an urge to move that relieved symptoms (video on the Neurology ${ }^{\circledR}$ Web site at Neurology.org). To date, few observations have been reported on arm restlessness and periodic movements of the upper limbs. ${ }^{1,2}$ This variant shares common features with restless legs syndrome and periodic limb movement disorder, such as therapeutic response to dopaminergic agonists. Clinicians should be aware of restlessness of the upper limbs, which likely remains underdiagnosed and requires appropriate therapeutic management.

Elisabeth Ruppert, MD, PhD, Christine Tranchant, MD, PhD, Ulker Kilic-Huck, MD, Nicolas Carpentier, MD, Marc Bataillard, MD, Patrice Bourgin, MD, PhD

From the Sleep Disorders Center (E.R., U.K.-H., N.C., M.B., P.B.), FMTS, Hôpital Civil, University of Strasbourg; Institute for Cellular and Integrative Neurosciences (E.R., U.K.-H., M.B., P.B.), CNRS-UPR 3212, Strasbourg; and the Center for Movement Disorders (C.T.), Hôpital de Hautepierre, University of Strasbourg, France.

Author contributions: E.R. and P.B. conceived of the design of the case report. E.R., C.T., N.C., and U.K.-H. were involved in the acquisition of data. E.R., N.C., and U.K.-H. performed the analysis and interpretation of the data. E.R. and U.K.-H. wrote the submitted manuscript. C.T. and P.B. performed a critical revision of the submitted material.

Study funding: No targeted funding reported.

Disclosure: The authors report no disclosures relevant to the manuscript. Go to Neurology.org for full disclosures.

Correspondence to Dr. Ruppert: elisabeth.ruppert@chru-strasbourg.fr

1. Michaud M, Chabli A, Lavigne G, Montplaisir J. Arm restlessness in patients with restless legs syndrome. Mov Disord 2000;15: 289-293.

2. Ruppert E, Cretin B, Meyer C, Kilic-Huck U, Bourgin P. Characterization of periodic upper limb movement disorder in a patient with restless arms syndrome. Mov Disord 2012;27:1459-1461. 


\section{Neurology}

\section{Bedtime-related jerks in the upper limbs associated with restless arms syndrome Elisabeth Ruppert, Christine Tranchant, Ulker Kilic-Huck, et al.}

Neurology 2015;84;959

DOI 10.1212/WNL.0000000000001306

This information is current as of March 2, 2015

$\begin{array}{ll}\begin{array}{l}\text { Updated Information \& } \\ \text { Services }\end{array} & \begin{array}{l}\text { including high resolution figures, can be found at: } \\ \text { http://n.neurology.org/content/84/9/959.full }\end{array} \\ \text { Supplementary Material } & \text { Supplementary material can be found at: } \\ \text { http://n.neurology.org/content/suppl/2015/02/28/WNL.0000000000001 } & 306 . D C 1 \\ & \text { This article cites } 2 \text { articles, } 0 \text { of which you can access for free at: } \\ & \text { http://n.neurology.org/content/84/9/959.full\#ref-list-1 } \\ \text { References } & \text { This article, along with others on similar topics, appears in the } \\ & \text { following collection(s): } \\ \text { Insomnia } & \text { http://n.neurology.org/cgi/collection/insomnia } \\ \text { Restless legs syndrome } & \text { http://n.neurology.org/cgi/collection/restless_legs_syndrome } \\ & \text { Information about reproducing this article in parts (figures,tables) or in } \\ & \text { its entirety can be found online at: } \\ \text { http://www.neurology.org/about/about_the_journal\#permissions } & \text { Information about ordering reprints can be found online: } \\ \text { Permissions \& Licensing } & \text { http://n.neurology.org/subscribers/advertise }\end{array}$

Neurology ${ }^{\circledR}$ is the official journal of the American Academy of Neurology. Published continuously since 1951, it is now a weekly with 48 issues per year. Copyright (C 2015 American Academy of Neurology. All rights reserved. Print ISSN: 0028-3878. Online ISSN: 1526-632X.

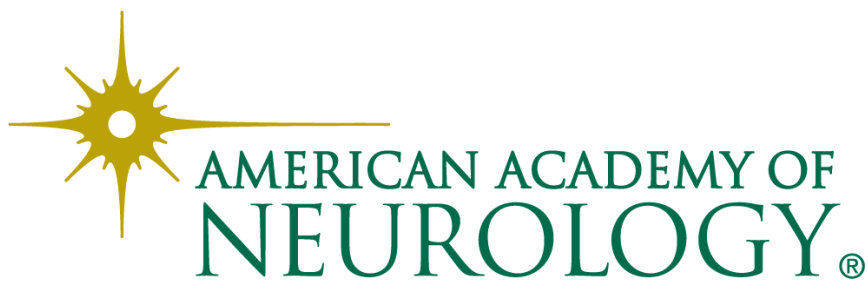

